\title{
The Popular Appeal of the Near-Death Experience
}

\author{
Robert Basil, M.A. \\ Prometheus Books, Buffalo, NY
}

\begin{abstract}
In this article I argue that as scientific research provides an ever-more-complete physiological explanation of the near-death experience (NDE), popular interest in NDEs will wane, because the transcendental interpretation, which holds that the NDE provides proof of an immaterial soul, an afterlife, and assorted paranormal phenomena, has always been the magnet that has attracted widespread attention to the subject. Since the transcendental interpretation resonates with our culture's deepest wishes, dreams, and fears, the television and newspapers have tended to focus on that model almost exclusively. This unbalanced presentation of near-death research has reinforced the traditional image of science as a cold, heartless enterprise. I speculate that, in terms of its popular appeal, future near-death research may well have more impact on the field of psychotherapy than that of religion or the paranormal.
\end{abstract}

While other essays in this tenth-anniversary issue of The Journal of Near-Death Studies describe advances the scientific community has been making in the study of near-death experiences (NDEs) and how that community can continue its research most effectively, I wish to slice into the discussion from a more marginal position. I will try to answer the following question: what impact will future research on NDEs have on the popular understanding of them? Or, putting it more frankly, this essay will explain why I think that future scientific

Robert Basil, M.A., is a senior editor at Prometheus Books, and a Ph.D. candidate in American popular culture and religion at Stanford University. He has taught at Stanford University and at Villa Maria College. Reprint requests should be addressed to Mr. Basil at Prometheus Books, 700 East Amherst Street, Buffalo, NY 14215-1674. 
insight will have little or no effect on the popular understanding of NDEs.

In "A Neurobiological Model for Near-Death Experiences," Juan C. Saavedra-Aguilar and Juan S. Gómez-Jeria (1989), summarizing relevant research, wrote that "being really near death does not appear to be a necessary condition to having an NDE" (p. 207). In the conclusion to this important article, the authors flatly reject the religious or "transcendental" model

in the light of present knowledge. Recent neurological analysis of some religious events ... which seem to correlate well with epileptic phenomenology, suggest that we are on the right path in separating physical elements from metaphysical ones. (Saavedra-Aguilar and Gómez-Jeria, 1989, p. 218)

This "transcendental interpretation" has not been universally rejected by the scientific community, as a brisk exchange in the British journal The Lancet has shown. Justine Owens, Emily Cook, and Ian Stevenson (1990) studied 58 patients who reported having NDEs, only 28 of whom were actually near death. They reported "one item relevant to the transcendental interpretation. ... [W]e found that patients who were actually near death reported enhanced cognitive function at that time" (p. 1177). In a letter to the editor, Karl Jansen replied:

Until objective testing of the cognitive function in dying persons claiming improved function is done the well established paradigms of physical science stand firm against transcendental interpretations. (1991, p. 244)

Bruce Greyson, the editor of this journal, has bluntly noted that NDEs offer poor proof of an afterlife, as quoted in a syndicated newspaper article (Shulins, 1989) representative of the manner in which print journalism treats the NDE. The author quoted Greyson, who stressed the psychological after-effects of the NDE, but devoted most of the article to the transcendental interpretation. Three NDErs were interviewed and told of meeting God, being cradled by a deceased mother during the NDE, and being encompassed by a white light subsequently labeled as God; a Tufts University professor, who was called a "debunker," was given three paragraphs (in a 49-paragraph article) to counter claims that these and other NDErs really died and came back.

Even Raymond Moody, who introduced the subject of NDEs to millions in his Life After Life (1975)-a book that unabashedly promoted 
the hypothesis that NDErs have, in fact, glimpsed some transcendental world-admitted that science has not shown that the near-death experience provides evidence of an afterlife:

I have talked to almost every NDE researcher in the world about his or her work. Most of us believe in our hearts that NDEs are a glimpse of life after death. But as scientists and people of medicine, we still haven't come up with "scientific proof" that part of us goes on living after our physical being is dead. (Moody and Perry, 1988, p. 151)

Moody's book is filled with incorrect information. His claim that "there are many cases in which people with flat EEGs have had near-death experiences" (Moody and Perry, 1988, p. 142) has no support or corroboration in the medical literature; Greyson noted that "no physician or scientist has yet published a firsthand report with EEG findings" (1990, p. 258). Moody's claim that the NDE is "something specifically connected with being on the brink of death" $(1988$, p. 141) has been proven false by numerous accounts given by NDErs themselves, as well as by research such as that of Owens, Cook, and Stevenson (1990) noted above. A leap of faith is required to accept Moody's hypothesis.

In short, research conducted under scientific conditions seems to demonstrate, and more and more convincingly, that NDEs have a wholly physiological cause, notwithstanding the pronounced emotional overlay that accompanies them-and notwithstanding, too, the religious/metaphysical/spiritual language with which that overlay is so commonly expressed.

This conclusion has been announced in the public forum. The "NDE debate" is now a talk-show staple; that's how I became involved in the field. A television talk-show was doing such a program, and the producer invited me to participate as a "skeptic" to counter five NDErs, each of whom held the metaphysical hypothesis; that is, each believed he or she had witnessed the afterlife. I had virtually no expertise in the area of near-death research; my research had focused on American fringe religious movements. Susan Blackmore had contributed to my anthology Not Necessarily the New Age (Basil, 1989), in which she devoted a few pages to out-of-body experiences and NDEs. I had edited that contribution on a trainride, and literally everything I knew about NDEs I had learned between Rochester and Poughkeepsie. For television, I thought, that ought to be enough.

The show's producer called the Committee for the Scientific Investigation of Claims of the Paranormal (CSICOP) and asked whom that haven of skeptics could provide. Since Blackmore lives in Great Bri- 
tain and none of the other regular suspects could be rounded up, CSICOP's media coordinator hoped I could acquit the skeptical position well. He made me promise to read his fat file on the subject, which I did, and he got me on the show ... after the second commercial and after several attractive, sincere, and articulate people told stirring, heartening stories of their souls' voyage into the astral worlds.

The hostess introduced me with this question: "Over 8 million people report having had a near-death experience. Why do you say they're lying?"

This debate, I realized at once-and with considerable force-was going to be rather limited. To doubt the prevalent interpretation of the NDE meant that one was an atheist, that one had no hope, that one's mind was closed. The near-death experience was the subject of the show only insofar as it cleared the way for discussion about spiritual growth and faith-proved-true. I did note, in fact, that many NDErs return from their experience with feelings of universal love, that there was no need to attack the experience itself, especially when its aftereffects seemed so manifestly beneficial. Nonetheless, the hostess nailed me with the kind of logical non sequitur that plays so well on television: "Don't you believe in love, Mr. Basil? Haven't you ever been in love?"

The cameras were showing audience members shaking their heads, apparently with disbelief and derision, as I pathetically protested, "I love love!"

"I'm sorry, that really wasn't fair of me," the hostess said. "So let me ask my audience: is there anybody here who agrees with what Mr. Basil is saying today?" After five seconds of silence-a long, long time on television-she summed up: "Okay then... We'll be right back after this message."

I cannot doubt that the appeal of the topic was, and remains, the promise that NDEs evince spiritual worlds, worlds you will get to eventually. That's an attractive promise, and it's one that courses through the veins of most religions.

Most of my "skeptic" friends were pleased with my appearance, though they freely admitted I was mauled. "That's the best we can hope for" was the refrain. Any kind of in-depth treatment of a scientific topic is impossible on television; there's not enough time to state one's case. Moreover, there's not enough time to counter somebody else's case. You can't check or refute claims; all you can do is talk. Whoever talks best wins the argument.

And it's hard to talk best when you're trying to talk science. Indeed, the complexity and the fruits of science are, I believe, the very things that make the New Age paradigm so savory in contrast. Science is 
associated with the technology that has given us nuclear weapons, with the pollution that threatens the health of our planet. This world is dangerous, confusing, and transient; so it's a good thing there's another realm, the spiritual realm, which is everlasting and good.

The scientist's world-view is beholden to a lesser reality. Psychologist Maureen O'Hara put it well:

The image of the mainstream scientist held by most New Agers is of a person, usually a white male, with no feelings, no spiritual yearnings, and who is probably oblivious to both the darker applications of his craft and to the magical possibilities of the human mind. The image of "science" is of a completely rational, reductionistic power-trip where "linear or left-brained thinking" and closed-mindedness predominate. (1989, p. 152)

The following exchange, televised on another television talk show, "The Shirley Show," on September 10, 1990, no doubt fortified that image:

Henry Gordon (Chairman of the Ontario Skeptics): The concept of the near-death experience is dangerous for a number of reasons. If one tends to believe in these things, one tends to believe in superstitious, supernatural, paranormal things. People tend to be less rational in their thinking. And Lord knows we need a lot more rational thinking today.

Barbara Harris (NDEr): I disagree. We need a lot less rational thinking. [Audience applauds.] It's out of balance to just be rational. A rational world has made the mess we got right now. I'm talking about heart, Henry.

Henry Gordon: I was born a skeptic. Basically because I don't like hypocrisy.... I'd like to see some of the evidence for some of the claims made here today. I'm going to be your party-pooper.

Television is all about leaping into new and wonderful worlds. The promise of most products advertised on television commercials is one of total, enchanting, and instant transformation. The near-death experience, as told by most NDErs who appear on talk shows, is all about leaping into a new and wonderful world and about becoming totally, enchantingly, and instantly transformed. Skeptics who attempt to explain the effects of asphyxiation on neuropeptides, or who make unwarranted ad hominem attacks, aren't going to leap too far. I can do no better than to quote media critic Jay Rosen:

Television is not in the business of disputing beliefs. It is more likely to entertain them, as a way of entertaining us. When New Agers 
appear on such programs as Phil Donahue or Oprah Winfrey, they are there to discuss holistic health or reincarnation as "controversies," equivalent in their entertainment value to incest, patricide, and men who love fat women. The hosts may stir up some opposition in the audience, or invite a skeptic on to dispute the New Agers. But as representatives of an emergent lifestyle, New Age thinkers are likely to be greeted with the different-strokes-for-different-folks attitude that serves as the unofficial ideology of the Donahue-Winfrey format. (1989, p. 271)

Barbara Harris's book, Full Circle: The Near-Death Experience and Beyond (Harris and Bascom, 1990), illustrates the ways in which NDErs have come to interpret their experiences, and it sets out clearly why "skeptics," not to mention scientists generally, will never be able to define NDEs in ways that win large public acceptance.

It goes without saying that NDErs rarely expect their experiences, and that their experiences seem strange yet also more "real" than waking consciousness. Because of that sense of "reality," most NDErs will reject a hypothesis that they were merely hallucinating. Hallucinations can be vivid, and they can mimic many aspects of the NDE, but rarely do those who hallucinate interpret their hallucinations, after they have passed, as being actual events, no matter what information they may have gleaned from the hallucination.

A compelling analogy can be found in the film The Wizard of $\mathrm{Oz}$ (LeRoy and Fleming, 1939). Dorothy's adventures along the yellow brick road seemed real to her, though they were brought on by a sharp bump on the head. Returning to normal consciousness by the film's end, Dorothy retained those insights gained in her dream/fantasy/ hallucination. It is of note that the adventures of Dorothy and her dog Toto in $\mathrm{Oz}$ were filmed in color; while their life in Kansas, representing a more mundane experience, was filmed in black-and-white.

Because of this sense of "reality" to the experience, being told that your NDE is a hallucination brought on, for example, by cerebral anoxia (Hines, 1988) is not going to satisfy you. In fact, how could such an explanation not infuriate you? Who wants the most profound experience of one's life explained away with one word: hallucination? An NDEr wants more than one word. And the reason that up until recently most NDErs have accepted the paranormal/transcendental hypothesis is this: those who embrace that hypothesis established a taxonomy of, and a vocabulary for, the experience first; they gave shape to the inchoate, gave NDErs a conceptual grip on the experience. Who would not choose the serious conjectures of the paranormal researcher or the spiritualist over the debunker's one-word dismissal? 
You listen to the people who listen to you; you don't listen, or have a hard time trying to listen, to people who don't. The paranormal researchers and spiritualists were the ones who originally listened to NDErs.

Harris's response to her NDE, as described in Full Circle, depicts well this role of the paranormal researcher. Bewildered by her experience, Harris delved into the literature, the initial effect of which was to give names to what she saw and felt: "I had never really thought of it as a tunnel until recently, when I started reading all the literature on NDEs, but I knew that was a good word for it" (Harris and Bascom, 1990, p. 91). That literature also supported a number of paranormal claims, including one that NDErs show an increase in psychic abilities. Harris herself wrote:

My bio-energy field, the result of the NDE, affects electronic equipment. The energy affects anything that uses microchips, including computers and photocopy machines. Ordinary car batteries are sometimes drained when I'm around them... . The up side is that burnedout light bulbs sometimes work again around me. The down side is that streetlamps sometimes blow out as I walk past them. (Harris and Bascom, 1990, p. 139)

The importance of attaching words to these experiences was echoed by Blackmore, who began research into psychic phenomena after an out-of-body experience and then became a skeptic after conducting many tests that failed to establish the existence of psychic phenomena. She has retained an admiration for those who champion the paranormal hypothesis, noting in particular the role it plays in giving people language: "Astral projection, mystical insight, cosmic consciousness, and ineffable oneness are not ridiculous ideas to be laughed at but people's brave attempts to describe their experience" $(1989$, p. 183).

Of all experiences that can be called paranormal, the NDE is unique. Here is an alleged experience of the afterlife that can actually be looked at under more or less controlled conditions, for example in hospitals. Here, finally, science might no longer be able to deny the existence of the soul, of consciousness floating free from visceral support. The experiment is clear: if someone can report having an NDE after his or her electroencephalogram has been flat for a while, then scientists must accept that some form of human consciousness is independent of the brain. The thin edge of the wedge was described precisely by Charles Tart (Blackmore, 1983, p. 230): "Man has a nonphysical soul of some sort that is capable, under certain conditions, of leaving the physical body." 
I predict that as researchers close in on a wholly physiological explanation for NDEs, popular interest in them will wane, because people come to the topic out of hope and that hope will be dashed. If medicine figures out how to induce an NDE safely, how to excite the beneficial effects described so eloquently by Harris and many others, then interest will no doubt rise again, but it will rise among those who are interested in psychotherapy and not in proof of the afterlife or an immaterial soul.

It is impossible to predict whether such a drug or treatment will ever be invented, or how-or how often and to how many-it would be prescribed, or what society would look and act like when it is filled with self-knowing people-lovers whose fear of death has vanished. It does seem, however, that profoundly effective psychotherapy available on such a wide scale would warrant the same kind of debate now generated by the possibility of improving our biological make-up with designer genes.

\section{References}

Basil, R. (Ed.). (1989). Not necessarily the New Age: Critical essays. Buffalo, NY: Prometheus Books.

Blackmore, S. (1983). Out of the body. London: Granada.

Blackmore, S. (1989). Out of the body? In Basil, R. (Ed.), Not necessarily the New Age: Critical essays. Buffalo, NY: Prometheus Books.

Greyson, B. (1990). Scientific commentary. In Harris, B., and Bascom, L., Full circle: The near-death experience and beyond. New York, NY: Pocket Books.

Harris, B., and Bascom, L. (1990). Full circle: The near-death experience and beyond. New York, NY: Pocket Books.

Jansen, K.L.R. (1991). Transcendental explanations and near-death experience (letter). Lancet, 337, 244.

LeRoy, M. (Producer), and Fleming, V. (Director). (1939). The Wizard of $\mathrm{Oz}$ (Film). Hollywood, CA: Metro-Goldwyn-Mayer.

Moody, R.A., Jr. (1975). Life after life. Covington, GA: Mockingbird Books.

Moody, R.A., Jr., and Perry, P. (1989). The light beyond. New York, NY: Bantam.

O'Hara, M. (1989). Science, pseudoscience, and mythmongering. In Basil, R. (Ed.), Not necessarily the New Age: Critical essays. Buffalo, NY: Prometheus Books.

Owens, J.E., Cook, E.W., and Stevenson, I. (1990). Features of "near-death experience" in relation to whether or not patients were near death. Lancet, 336, 1175-1177.

Rosen, J. (1989). Optimism and dread: T.V. and the New Age. In Basil, R. (Ed.), Not necessarily the New Age: Critical essays. Buffalo, NY: Prometheus Books.

Saavedra-Aguilar, J.C., and Gómez-Jeria, J.S. (1989). A neurobiological model for neardeath experiences. Journal of Near-Death Studies, 7, 205-222.

Shulins, N. (1989, June 25). Seeing the light. Associated Press syndicated article. 